\title{
Carcass characteristics, physicochemical changes and oxidative stress indicators of meat from sheep fed diets with coffee pulp
}

\author{
[Características de carcaça, alterações físico-químicas e indicadores de estresse oxidativo \\ de carne de ovinos alimentados com dietas com polpa de café]
}

\author{
T. Salinas-Rios ${ }^{1}$, M.T. Sánchez-Torres-Esqueda ${ }^{1 *}$, J. Hernández-Bautista ${ }^{2}$, A. Díaz-Cruz ${ }^{3}$, \\ C. Nava-Cuellar ${ }^{3}$, M.E. Ortega-Cerrilla ${ }^{1}$, J.L. Cordero-Mora ${ }^{1}$, H. Vaquera-Huerta ${ }^{4}$, J.L.F. Velasco ${ }^{1}$ \\ ${ }^{1}$ Programa de Ganadería - Colegio de Postgraduados. Carretera México-Texcoco - Estado de México. México \\ ${ }^{2}$ Escuela de Medicina Veterinaria y Zootecnia - Universidad Autónoma Benito Juárez de Oaxaca - México \\ ${ }^{3}$ Universidad Nacional Autónoma de México - México \\ ${ }^{4}$ Programa de Estadística - Colegio de Postgraduados - México
}

\begin{abstract}
The purpose of this study was to determine how feeding sheep coffee pulp affects carcass characteristics and what changes occur in physicochemical, antioxidant capacity and oxidation of the meat during refrigerated storage. The experiment was carried out in 15 Blackbelly lambs weighing an average $22.86 \pm 0.76 \mathrm{~kg}$. The animals were assigned to three treatments: $\mathrm{T} 0=$ control diet, $\mathrm{T} 1=$ diet with $8 \%$ coffee pulp, and T2=diet with $16 \%$ coffee pulp. After fattening for 56 days, the sheep were slaughtered and the carcasses assessed. The inclusion of $16 \%$ coffee pulp in the diet increased carcass dressing from 48.19 to $50.83 \%$ and decreased the amount of fat in rumen and intestines from 3.43 to $2.53 \%(\mathrm{P}<0.05)$. The inclusion of coffee pulp in the diet did not alter the amount of crude protein or fat in meat or its oxidation and antioxidant capacity during refrigerated storage. However, the inclusion of coffee pulp in the diet decreased fat in the rumen and intestines, and thus increased the amount of usable meat.
\end{abstract}

Keywords: antioxidant, carcass, dressing percent, fat

\section{RESUMO}

Objetivou-se determinar características de carcaça, alterações físico-químicas, capacidade antioxidante e de oxidação da carne de ovinos alimentados com polpa de café, durante o período de armazenamento refrigerado. O experimento foi realizado com 15 cordeiros Blackbelly com um peso médio de 22,86 \pm $0,76 \mathrm{~kg}$. Os animais foram distribuídos em três tratamentos: $T 0=$ dieta controle, $T 1=$ dieta com $8 \%$ de polpa de café e T2=dieta com polpa de café de 16\%. Depois de 56 dias de engorda, cordeiros foram abatidos, e a carcaça avaliada. Inclusão de polpa de café de $16 \%$ na dieta aumentou o rendimento de carcaça de 48.19 para 50.83\% e diminuiu a quantidade de gordura no rúmen e nos intestinos de 3.43 para $2.53 \%(P<0,05)$. A inclusão de polpa de café na dieta não alterou a proteína ou a gordura na carne nem a oxidação e a capacidade antioxidante durante o armazenamento refrigerado. A inclusão de polpa de café na dieta de cordeiros diminui a gordura no rúmen e nos intestinos e aumenta a quantidade de carne na carcaça.

Palavras-chave: antioxidante, carcaça, gordura

\section{INTRODUCTION}

Oxidation causes changes in physicochemical characteristics of meat, which affect consumer acceptance. In order to delay oxidation and retain meat color, different types of antioxidants have been used, and the most widely used is vitamin $\mathrm{E}$ (Wood and Enser, 1997; Macit et al., 2003). Although synthetic antioxidants have shown

Recebido em 10 de junho de 2014

Aceito em 1 de dezembro de 2014

Autor para correspondência (corresponding author)

E-mail: teresa@colpos.mx 
satisfactory results, consumers are looking to more natural products; thus, recently, there has been interest in assessing antioxidant-rich plants as animal feed with the aim of increasing meat shelf life (Luciano et al., 2009; Karami et al., 2010; Smeti et al., 2013).

Coffee pulp is a byproduct that is highly available in coffee growing zones. In the first step of processing coffee, the fruit is separated from the coffee bean and discarded. This fruit pulp, however, has been found to contain phenolic compounds (Ramirez-Coronel et al., 2004) that have proven to be powerful antioxidants (Sroka and Cisowski, 2003). Coffee pulp contains significant amounts of caffeine (Ferreira et al., 2001), which reduces the concentrations of internal fat and meat fat (Poornahavandi and Zamiri, 2008). The purpose of this experiment was to determine the effect of coffee pulp in sheep diets on carcass characteristics, as well as on physicochemical changes, antioxidant capacity and oxidation of meat during refrigerated storage.

\section{MATERIALS AND METHODS}

The present study was performed according to the norms of ethics and biosafety of the Colegio de Postgraduados, Campus Montecillo, México.

The coffee (Coffea Arabica) pulp was ensiled with 5\% molasses, fermented for two months, and sun-dried dehydrated in the sun. The coffee pulp used contained $0.50 \%$ caffeine and antioxidants such as chlorogenic acid (5.61\%), caffeic acid (1.47\%) and gallic acid (0.26\%).

In order to measure the antioxidant capacity of the diets, antioxidant extraction was done according to the technique described by Restrepo et al. (2009). The antioxidant capacity was then determined using the FRAP technique by Benzie and Strain (1999).

Fifteen Blackbelly lambs, with an initial weight of $22.86 \pm 0.60 \mathrm{~kg}$ and average age of 6 months, were assigned to one of three treatments: T0 $=$ control diet $(n=5), T 1=$ diet with $8 \%$ coffee pulp $(\mathrm{n}=5)$, and $\mathrm{T} 2=$ diet with $16 \%$ coffee pulp $(n=5)$ (Table 1). The experimental design was completely randomized. After a 12 day period of adaptation to the diet, the lambs were fed the treatment diets for 56 days.

At the end of the fattening period the animals were slaughtered after a 12 hour fasting period with no water restriction. Average weights were $32.76 \pm 0.92,33.06 \pm 0.92$, and $33.18 \pm 0.92 \mathrm{~kg}$ for $\mathrm{T} 0$, T1, and $\mathrm{T} 2$, respectively. Carcass dressing was determined by dividing the weight of the hot carcass by the slaughter weight. Fat in the rumen, intestines and kidneys was removed manually and determined as percentage of slaughter weight. Carcasses were hung and refrigerated for $24 \mathrm{~h}$ at $3-4 \circ \mathrm{C}$.

Table 1. Ingredients, chemical composition and antioxidant capacity of the diets with different concentrations of coffee pulp in sheep fattening diets

\begin{tabular}{llll}
\hline \multirow{2}{*}{ Ingredient (\%) } & \multicolumn{2}{c}{ Treatments } \\
\cline { 2 - 4 } Alfalfa hay & T0 & T1 & T2 \\
Ground sorghum grains & 57.57 & 48.53 & 21.50 \\
Soy meal & 25.24 & 22.76 & 20.20 \\
Molasses & 14.18 & 17.69 & 2.00 \\
Mineral mixture & 2.00 & 2.00 & 1.00 \\
Silaged coffee pulp & 1.00 & 1.00 & 16.00 \\
\hline Crude protein & 0.00 & 8.00 & 14.40 \\
Metabolizable energy (Mcal/kg) & 14.32 & 14.35 & 2417.5 \\
\hline Antioxidant capacity & 2414 & 2416 & \\
FRAP ( $\mu$ g trolox/g DM) & 32.20 & 37.58 & 40.25 \\
\hline
\end{tabular}

The $\mathrm{pH}$ was measured between the twelfth and thirteenth ribs of the cold carcass. The right longissimus dorsi muscle of each animal was collected and cut between the twelfth and thirteenth ribs; the rib-eye area (REA) was then measured using a $0.25 \mathrm{~cm}^{2}$ grid. The longissimus dorsi was divided into two fragments. 
The first meat fragment was used to determine moisture, crude protein, fat, and ash using the AOAC (1990) technique.

The second meat fragment was placed under refrigeration $\left(5^{\circ} \mathrm{C}\right)$ and color was measured through colorimetry. Luminosity ( $\left.\mathrm{L}^{*}\right)$, intensity from red to green $\left(\mathrm{a}^{*}\right)$, and intensity from yellow to blue $\left(b^{*}\right)$ were determined on the first day and then every third day until day 19.

In each sampling for color evaluation, a duplicate 10-gram sample of meat was collected, placed in cryostat tubes, and stored in liquid nitrogen at $196{ }^{\circ} \mathrm{C}$ until their analysis.

For analysis, the meat was homogenized with 10 $\mathrm{mL}$ of Krebs Ringer buffer, then centrifuged at 4,000 rpm for 5 minutes. The supernatant was used to determine antioxidant capacity and lipid peroxidation.

Antioxidant capacity was measured using the Benzie and Strain (1999) ferric reducing antioxidant power (FRAP) assay. Pattern curves were done with trolox (6-hydroxy-2-5-7-8tetramethylchroman-2-carboxylic acid). Samples were read by spectrophotometry at $593 \mathrm{~nm}$. Lipid peroxidation was measured by testing thiobarbituric acid reactive substances (TBARS) according to the technique described by Ohkawa et al. (1979). The results were calculated using malondialdehyde (MDA), obtained from 1,1,3,3tetraethoxypropane by acid hydrolysis. The samples were read by spectrophotometry at $532 \mathrm{~nm}$.

Protein was determined using the Bradford (1976) method. Data were reported in mg. A Thermo Scientific UV-V15 spectrophotometer was used for the analyses.
For the carcass and chemical composition variables, an analysis of variance was done using slaughter weight of the sheep as a co-variable, and when significance $(\mathrm{P}<0.05)$ was detected. A Tukey test comparison of means test was done using SAS ver. 9 (SAS, 2002) statistical software. To assess color and oxidative state of the meat during refrigerated storage, an analysis of variance was done using the following statistical model:

$Y_{i j k}=\mu+T_{i}+M_{j}+T_{i} M_{j}+A_{k}(i)+E_{i j k}$.

Where:

$Y_{i j k}=$ represents the $i^{\text {th }}$ treatment of the $j^{\text {th }}$ sample of the $k^{\text {th }}$ repetition, $\mu=$ general mean, $T_{i}=$ effect of the $\mathrm{i}^{\text {th }}$ treatment, $\mathrm{M}_{\mathrm{j}}=$ effect of the $\mathrm{j}^{\text {th }}$ sampling, $T_{i} M_{j}=$ effect of the $i^{\text {th }}$ treatment on the $j^{\text {th }}$ sampling, $A_{k}\left({ }_{i}\right)=$ effect of the $i^{\text {th }}$ treatment nested in the $\mathrm{k}^{\text {th }}$ animal and $\mathrm{E}_{\mathrm{ijk}}=$ experimental error.

\section{RESULTS}

Composition of the diets and their antioxidant capacity is shown in Table 1 . It can be seen that as the amount of coffee pulp increased in the diet, the antioxidant capacity also increased.

Carcass dressing was 48.19, 50.30, and 50.83\% for diets that had 0,8 and 16\% coffee pulp, respectively. It can be seen that as the amount of coffee pulp in the diet increases, the carcass dressing also increases. The addition of $16 \%$ coffee pulp to the diet decreased rumen and intestinal fat from 3.43 to $2.53 \%$ relative to live weight. Mean kidney fat, $\mathrm{pH}$, and REA were not modified as an effect of coffee pulp in the diet of sheep (Table 2).

The percentages of moisture, fat, protein, and ash in the sheep meat did not vary as an effect of including coffee pulp in the diet of sheep (Table 3).

Table 2. Carcass yields, fat, and rib-eye area of Blackbelly sheep fed diets with different levels of coffee pulp

\begin{tabular}{lllll}
\hline \multirow{2}{*}{ Characteristic } & \multicolumn{3}{c}{ Treatments } & SEM \\
\cline { 2 - 4 } & T0 & T1 & T2 & 0.35 \\
\hline Carcass dressing (\%) & $48.19 \mathrm{~b}$ & $50.30 \mathrm{ab}$ & $50.83 \mathrm{a}$ & 0.11 \\
Rumen and intestinal fat (\%) & $3.43 \mathrm{a}$ & $2.95 \mathrm{ab}$ & $2.53 \mathrm{~b}$ & 0.07 \\
Kidney fat (\%) & $0.76 \mathrm{a}$ & $0.84 \mathrm{a}$ & $0.73 \mathrm{a}$ & 0.03 \\
$\mathrm{pH}^{\mathrm{a}}$ & $5.75 \mathrm{a}$ & $5.75 \mathrm{a}$ & $5.80 \mathrm{a}$ & 0.263 \\
Rib-eye Area (\%) & $10.74 \mathrm{a}$ & $10.38 \mathrm{a}$ & $11.55 \mathrm{a}$ & \\
\hline
\end{tabular}

T0: control, T1: diet with $8 \%$ coffee pulp, T2: diet with $16 \%$ coffee pulp.

${ }^{\mathrm{a}} \mathrm{pH}$ measured $24 \mathrm{~h}$ post-mortem.

Different letters $(\mathrm{a}$ and $\mathrm{b})$ in a row indicate statistical difference $(\mathrm{P}<0.05)$. 
Table 3. Chemical composition of the longissimus dorsi from sheep fed diets with coffee pulp

\begin{tabular}{lllll} 
& \multicolumn{3}{c}{ Treatments } & SEM \\
\cline { 2 - 4 } & T0 & T1 & T2 & 0.84 \\
Moisture (\%) & 71.37 & 72.68 & 71.78 & 0.59 \\
Fat (\%) & 5.97 & 5.57 & 5.82 & 0.30 \\
Protein (\%) & 19.50 & 18.73 & 19.34 & 0.20 \\
Ash (\%) & 2.36 & 2.40 & 2.44 & \\
\hline
\end{tabular}

T0: control, T1: diet with $8 \%$ coffee pulp, T2: diet with $16 \%$ coffee pulp.

No differences $(\mathrm{P}>0.05)$ were observed among treatments.

Values of $\mathrm{L}^{*}$ and $\mathrm{a}^{*}$ were not modified by the treatments. Values of $\mathrm{b}^{*}$, however, decreased $(\mathrm{P}<0.05)$, relative to the control, as a result of including coffee pulp in the diet: 14.19 (with 0\%), 13.12 (with 8\%) and 13.38 (with 16\%).

Likewise, during refrigeration, color parameters varied little. $\mathrm{L}^{*}$ values were lower only on the first day $(\mathrm{P}<0.05)$ with no changes afterward. The values of $\mathrm{a}^{*}$ showed changes over time; they were statistically lower $(\mathrm{P}<0.05)$ on day 10 than on day 19. No significant differences were found on the other assessment days. Values of $b^{*}$ increased regularly from the first day until day 7 , when the maximum values were recorded; no further changes were observed on days 10, 13, 16, and 19 (Figure 1).

Antioxidant capacity was not modified by the treatments. Nevertheless, during refrigeration, trolox concentrations (Figure 2) increased slightly from day 1 (784.99 nmol trolox/mg protein) to day 4 (903.61 $\mathrm{nmol}$ trolox/mg protein), after which it decreased, reaching its lowest concentration on day $10(497.09 \mathrm{nmol}$ trolox/mg protein, $\mathrm{P}<0.05$ ).

Meat oxidation was not modified by the treatments. Under refrigeration, there were no signs of oxidation during the first four days. However, there was a notable $(\mathrm{P}<0.05)$ increase as of day 7 continuing until day 13, when peak oxidation occurred (18.00nmol MDA/mg protein, Figure 3).

\section{DISCUSSION}

Antioxidant capacity of the diets increased with higher percentages of coffee pulp. This is most probably due to the contents of phenolic compounds such as chlorogenic acid, caffeic acid, and gallic acid, which are compounds with antioxidant properties (Yen et al., 2002; Marinova et al., 2009).

The increase in carcass dressing of sheep fed coffee pulp is very important since it means more meat yield per animal. This increase was inversely related to rumen and intestinal fat deposition: when rumen fat decreased, carcass yield increased. Partida and Martínez (2010) reported that increasing the amount of body fat caused a reduction in the percentage of muscle. Thus, reducing rumen and intestinal fat with the addition of coffee pulp in the diets increased the proportion of meat. Reduction of rumen and intestinal fat is probably due to the $0.5 \%$ caffeine found in coffee pulp. Poornahavandi and Zamiri (2008) reported that when 80 and 100mg of caffeine and ephedrine were administered to lambs, internal fat and meat fat decreased. Spencer et al. (1983) reported that administering caffeine previous to slaughtering increases lipolysis. Hasegawa and Mori (2000) proved that green tea, which has $2.4 \%$ caffeine, has an anti-adipogenic effect, inhibiting the formation of fats, and a lipolitic effect, due to an increase in the level of cAMP. Thus, the increase in carcass dressing may be because the diets with coffee pulp reduced fat in the rumen and intestines. Since these are not part of the carcass, the ratio of carcass to live weight was greater.

Coffee pulp did not modify the $\mathrm{pH}$ of the meat. In this regard, Macit et al. (2003), when supplementing with $45 \mathrm{mg}$ vitamin $\mathrm{E}$, found that $\mathrm{pH}$ was not modified. Similarly, MajdoubMathlouthi et al. (2013) reported that the degree of inclusion of the concentrate and the weights at slaughtering did not modify the $\mathrm{pH}$ of the meat. 

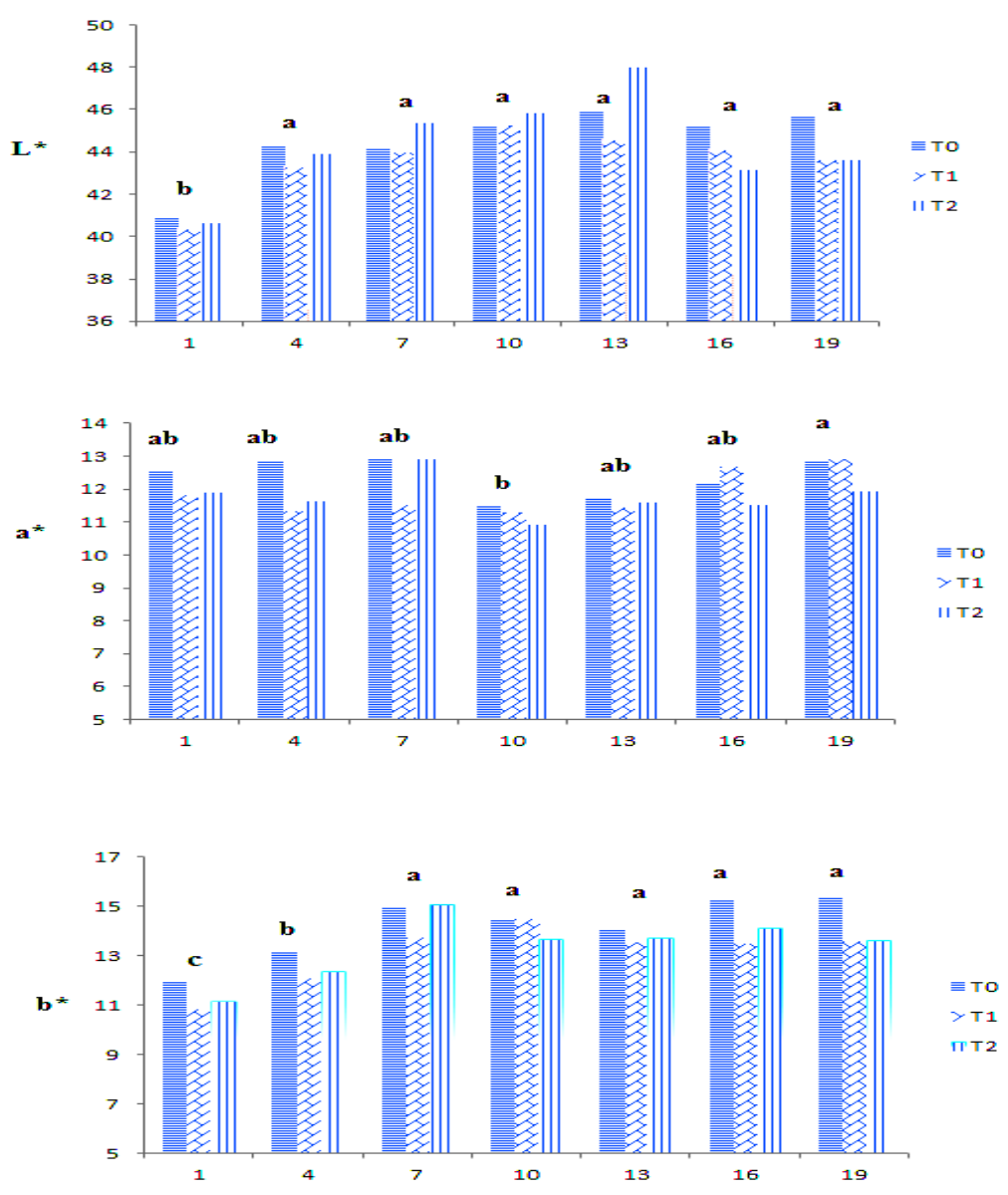

Figure 1. Changes in luminosity $\left(\mathrm{L}^{*}\right)$, red intensity $\left(\mathrm{a}^{*}\right)$, and yellow intensity $\left(\mathrm{b}^{*}\right)$ in meat from sheep fed coffee pulp during refrigerated storage. T0: control, T1: diet with 8\% coffee pulp, T2: diet with 16\% coffee pulp.

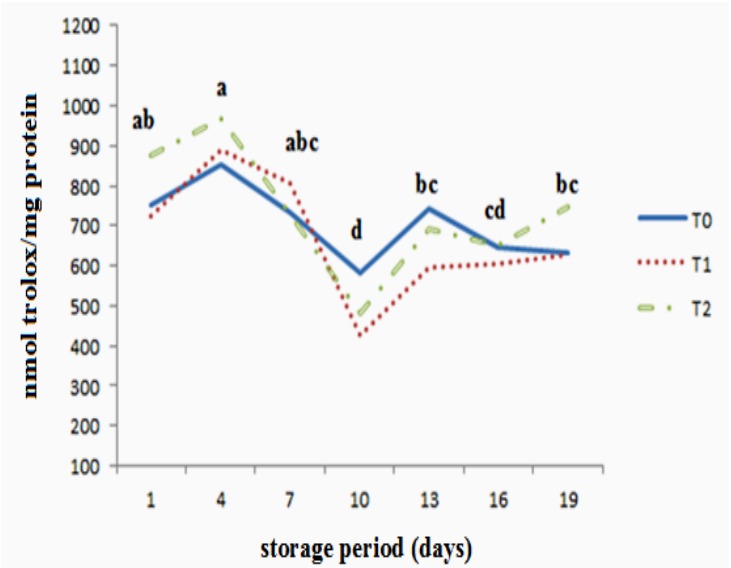

Figure 2. Antioxidant capacity during refrigerated storage of meat from sheep fed diets with different concentrations of coffee pulp. T0: control, T1: diet with $8 \%$ coffee pulp, T2: diet with $16 \%$ coffee pulp.

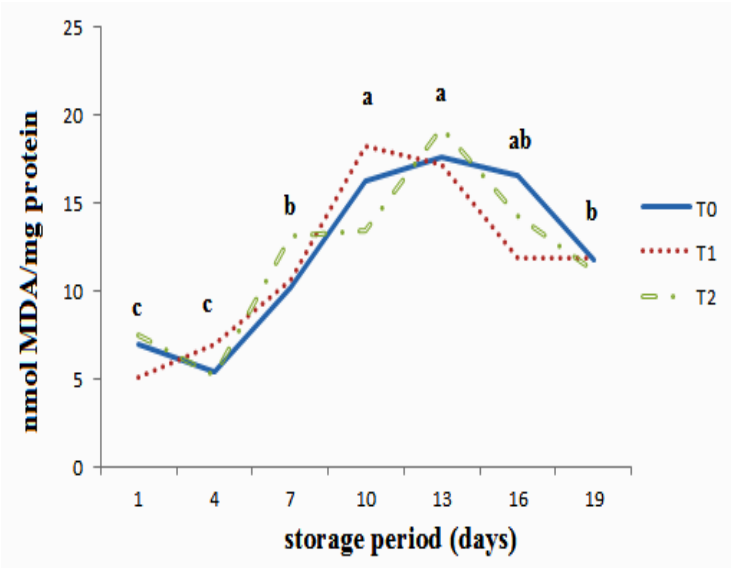

Figure 3. Oxidation during refrigerated storage in meat from sheep fed diets with different concentrations of coffee pulp. T0: control, T1: diet with $8 \%$ coffee pulp, T2: diet with $16 \%$ coffee pulp. 
The diets with coffee pulp did not modify REA. Measurement of the REA in the longissimus dorsi, together with other variables such as live weight, helps to predict the amount of muscle and fat yield in the carcass (Sahin et al., 2008) since REA correlates highly with live weight (Fernández et al., 1998). In the present study, sheep from all treatments showed similar weights at slaughter. Therefore, the influence of different percentages of coffee pulp in the diet may be more related to the final weight that animals reach when slaughtered. In the present study, sheep from all treatments showed similar weights at the time of slaughter.

Including coffee pulp in the diet did not modify the chemical composition of the meat. Although Poornahavandi and Zamiri (2008) reported that 80mg caffeine and 8mg ephedrine increased protein content in dry matter of the meat, this tendency in protein and fat was not found in our study. The difference in results may have been due to sheep weights at slaughter: in our experiment slaughter weights were around 33kg, while Poornahavandi and Zamiri (2008) slaughtered animals weighing more than $53 \mathrm{~kg}$. It has been reported that fattening to increase slaughter weight also increases fat deposition (Safdarian et al., 2008).

The inclusion of 8 and $16 \%$ coffee pulp decreased $b^{*}$ values, contrasting with Ripoll et al. (2013) and Sante'-Lhoutellier et al. (2008), who found that antioxidant inclusion had no effect on $b^{*}$ values. However, the values of $\mathrm{L}^{*}$ and $a^{*}$ in our study were not modified by diet antioxidants, relative to the control treatment. A possible reason that differences were not found may be that the control contained alfalfa hay, which has been proven to contain $11.5 \mathrm{mg}$ vitamin E/kg DM (Ripoll et al., 2013). In our study alfalfa hay was used, which is the crop residue remaining from the harvesting of alfalfa seeds. Even so, it probably contained considerable amounts of vitamin $E$. Supplementation with vitamin $\mathrm{E}$ for at least 20 days before slaughter has been found to decrease the concentration of oxymyoglobin, and thus stabilizes meat color (Ripoll et al., 2013). In our study, under refrigeration $\mathrm{L}^{*}$ values increased from day 1 to day 4, and then stabilized. These data agree with those reported by SantéLhoutellier et al. (2008), who found higher luminosity after day 0 of storage. On the other hand, Luciano et al. (2009), administering 8.9\% of quebracho (Schinopislorentzii), which contains tannins, found that meat became darker than that of the control diet as storage time increased.

Petron et al. (2007) observed that $\mathrm{a}^{*}$ values tended to decrease over time. Luciano et al. (2009) reported that this decrease is less pronounced in sheep fed fresh plants, and therefore diets rich in antioxidants tend to have higher reddening values during storage time. This is a consequence of the decrease in myoglobin oxidation, which ensures color stability and better appearance of the meat. In our experiment, lower values of $\mathrm{a}^{*}$ were observed only as of day 10 in all treatments.

The $b^{*}$ values have a tendency to increase with storage time, with higher values for the meat of sheep fed with concentrates (Luciano et al., 2009). Similar results were found in the present experiment, since the values of $b^{*}$ increased from day 1 to day 7 .

Although coffee pulp increased the antioxidant capacity of the diets, in sheep meat FRAP values were not modified. However, changes in FRAP values were found as an effect of refrigeration. There was no decrease in antioxidant capacity during the first 4 days, but by day 7 of storage antioxidant capacity began to decrease. The decrease that occurred on day 10 during storage is due to depletion of antioxidants used to counteract the oxidation process. Contrasting with our results, Luciano et al. (2011) found that meat from sheep fed with diets that included quebracho tree, which contains antioxidant compounds, had greater antioxidant capacity.

The TBARS technique measures lipid oxidation. In this experiment, all three diets were found to delay oxidation in meat up to day 4 , after which, however, accelerated oxidation was observed, with peak oxidation between days 10 and 13 of refrigerated storage. Jerónimo et al. (2012) found that malondialdehyde rapidly increases in sheep meat as of day 3 of storage. In our experiment we found increased levels of malondialdehyde as of day 7 of storage. Luciano et al. (2013) had similar findings, observing that concentrations of malondialdehyde increased as of day 8. The FRAP and TBARS values were inversely related: when FRAP values decreased, TBARS values 
increased. This is because the FRAP technique indirectly measures the amount of antioxidants present in the meat, so when these are depleted, oxidation increases notably. Different results have been found when diets are supplemented with antioxidants in terms of their effect on meat oxidation. Smeti et al. (2013), when evaluating rosemary essential oils, which contain phenolic compounds, did not find that the essential oils delay meat oxidation. Petron et al. (2007) reported that type of forage does not modify TBARS values. Karami et al. (2010), when supplementing goats with vitamin $\mathrm{E}$ and two plants with phenolic substances, found that all three diets decreased the TBARS values and protected the meat from lipid oxidation. It has also been reported that meat from animals fed with Vicia sativa have lower TBARS values over time (Luciano et al., 2009). Since coffee pulp was seen to increase the antioxidant capacity of the diets, it is necessary to continue assessing its inclusion in low antioxidant diets and at higher percentages to observe their effect on retaining meat color and delaying oxidation.

\section{CONCLUSIONS}

Coffee pulp, which contains phenolic acids and caffeine, increased carcass dressing and decreased fat in the rumen and intestines, and did not affect the oxidative stage of the meat.

\section{REFERENCES}

AOAC. Official Methods of Analysis. 15.ed. Association of Official Analytical Chemist. Washington, D.C.P. 1298, 1990.

BENZIE, I.F.; STRAIN, J.J. The ferric reducing ability of plasma (FRAP) as a measure of "antioxidant power": The FRAP assay. Analytical Biochemistry, v.239, p.70-76, 1996.

BRADFORD, M.M. A rapid and sensitive method for the quantitation of microgram quantities of protein utilizing the principle of protein-dye binding. Anal. Biochem., v.72, p.248-254, 1976.

FERNÁNDEZ, C.; GARCÍA, A.; VERGARA, H.; GALLEGO, L. Using ultrasound to determine fat thickness and longissimus dorsi area on Manchego lambs of different live weight. Small Rum. Res., v.27, p.159-165, 1998.
FERREIRA, B.A.; AGUIAR, P.P.; OLALQUIAGA, P.J. et al. Factores antinutricionais da casca e da polpa desidratada de café (Coffea arabica L.). Armazenadas em diferentes períodos. Rev. Bras. Zootec., v.30, p.1325-1331, 2001.

HASEGAWA, N.; MORI, M. Effect of powdered green tea and its caffeine content on lipogenesis and lipolysis in 3t3-L1 cell. J. Healt Sci., v.46, p.153-155, 2000.

JERÓNIMO, E.; ALFAIA, C.M.M.; ALVES, S.P. et al. Effect of dietary grape seed extract and Cistus ladanifer $\mathrm{L}$. in combination with vegetable oil supplementation on lamb meat quality. Meat Sci., v.92, p.841-847, 2012.

KARAMI, M.; ALIMÓN, A.R.; SAZILI, A.Q. Meat quality and lipid oxidation of infraspinatus muscle and blood plasma of goats under dietary supplementation of herbal antioxidants. J. Anim. Vet. Adv., v.9, p.3039-3047, 2010.

LUCIANO, G.; MONAHAN, F.J.; VASTA, V. et al. Dietary tannins improve lamb meat color stability. Meat Sci., v.81, p.120-125, 2009.

LUCIANO, G.; VASTA, V.; MONAHAN, F.J. et al. Antioxidant status, colour stability and myoglobin resistance to oxidation of longissimus dorsi muscle from lambs fed a tannin-containing diet. Food Chem., v.124, p.1036-1042, 2011.

LUCIANO, G.; BIONDI, L.; SCERRA, M. et al. The effect of the change from a herbage- to a concentrate-based diet on the oxidative stability of raw and cooked lamb meat. Meat Sci., v.95, p.212-218, 2013.

MACIT, M.; AKSAKAL, V.; EMSEN, E. et al. Effects of vitamin $E$ supplementation on performance and meat quality traits of Morkaraman male lambs. Meat Sci., v.63, p.5155, 2003.

MAJDOUB-MATHLOUTHI, L.; SAÏD, B.; SAY, A. et al. Effect of concentrate level and slaughter body weight on growth performances, carcass traits and meat quality of Barbarine lambs fed oat hay based diet. Meat Sci., v.93, p.557-563, 2013.

MARINOVA, E.; TONEVA, A.; YANISLIEVA, $\mathrm{N}$. Comparison of the antioxidative properties of caffeic and chlorogenic acids. Food Chem., v.114, p.1498-1502, 2009. 
OHKAWA, H.; OHISHI, N.; YAGI, K. Assay for lipid peroxides in animal tissues by thiobarbituric acid reaction. Anal. Biochem., v.95, p.351-358, 1979.

PARTIDA, P.J.A.; MARTÍNEZ, R.L. Composición corporal de corderos Pelibuey en función de la concentración energética de la dieta y del peso al sacrificio. Vet. México, v.47, p.313322, 2010

PETRON, M.J.; RAES, K.; CLAEYS, E. et al. Effect of grazing pastures of different botanical composition on antioxidant enzyme activities and oxidative stability of lamb meat. Meat Sci., v.75, p.737-745, 2007.

POORNAHAVANDI, H.R.; ZAMIRI, M.J. Effects of ephedrine and its combination with caffeine on body composition and blood attributes of fat-tailed Mehraban lambs. Iranian J. Vet. Res., Shiraz University, v.9, p.51-58, 2008.

RAMÍREZ-CORONEL, M.A.; MARNET, N.; KUMAR-KOLLI, V.S. et al. Characterization and estimation of proanthocyanidins and other phenolicsin coffee pulp (Coffee arabica) by thiolysis-high-performance liquid chromatography. J. Agric. Food Chem., v.52, p.1344-1349, 2004.

RESTREPO, S.D.; NARVÁEZ, C.C.; RESTREPO, S.L. Extracción de compuestos con actividad antioxidante de frutos de guayaba cultivada en Vélez-Santander, Colombia. Quim. Nova, v.32, p.1517-1522, 2009.

RIPOLL， G.; GONZÁLEZ-CALVO, L.; MOLINO, F. et al. Effects of finishing period length with vitamin $\mathrm{E}$ supplementation and alfalfa grazing on carcass color and the evolution of meat color and the lipid oxidation of light lambs. Meat Sci., v.93, p.906-913, 2013.
SAFDARIAN, M.; ZAMIRI, M.J.; HASHEMI, M.; NOOROLAHI, H. Relationships of fat-tail dimensions with fat-tail weight and carcass characteristics at different slaughter weights of Torki-Ghashghaii sheep. Meat Sci., v.80, p.686689, 2008.

SAHIN, E.M.; YARDIMCI, M.; CENTINGUL, I.S. et al. The use of ultrasound to predict the carcass composition of live Akkaraman lambs. Meat Sci., v.79, p.716-721, 2008.

SANTE'-LHOUTELLIER, V.; ENGEL, E.; GATELLIER, P. Assessment of the influence of diet on lamb meat oxidation. Food Chem., v.109, p.573-579, 2008.

STATISTICAL Analisys System - SAS Proceeding Guide, versión 9. SAS Institute. Cary NC. USA. 2002.

SMETI, S.; ATTI, N.; MAHOUACHI, M.; MUNOZ, F. Use of dietary rosemary (Rosmarinus officinalis L.) essential oils to increase the shelf life of Barbarine light lamb meat. Small Rum. Res., v.113, p.340-345, 2013.

SPENCER, G.S.G.; WILKINS, L.J.; LISTER, D. Caffeine stimulated lipolysis protects pig against catecholamine-induced dark cutting. Meat Sci., v.8, p.53-64, 1983.

SROKA, Z.; CISOWSKI, W. Hydrogen peroxide scavenging, antioxidant and anti-radical activity of some phenolic acids. Food and Chemical Toxicol., v.41, p.753-758, 2003.

WOOD, J.D.; ENSER, M. Factors influencing fatty acids in meat and the role of antioxidants in improving meat quality. British J. Nutrit., v.78, p.49-60, 1997.

YEN, G.C.; DUH, P.D.; TSAI, H.L. Antioxidant and pro-oxidant properties of ascorbic acid and gallic acid. Food Chem., v.79, p.307-313, 2002. 